\author{
Krzysztof Obremski ${ }^{1}$
}

\title{
PANEGIRYK BISKUPI PRUS KRÓLEWSKICH? BISKUPI CHEŁMIŃSCY STANISŁAW HOZJUSZ I KAZIMIERZ JAN OPALINSKI
}

\author{
Podniosłe stwierdzenia o odnowieniu \\ czci Najświętszego Sakramentu \\ i o zasługach w tym względzie biskupa \\ chełmińskiego Kazimierza Jana \\ Opalińskiego okażą się konwencją \\ stylistyczną rodem z panegiryku².
}

Kiedy kilka lat temu zająłem się panegirykiem królewskim jako odmianą gatunkową zdeterminowaną osobą monarchy ${ }^{3}$, wówczas przedstawiłem propozycję nowego pojmowania panegiryku (zakwestionowałem ,panegiryczną przesadę" z powodu kłopotów, jakie stwarza wyznaczenie granicy, poza która pochwała staje się przesadna) i jedynie pomyślałem sobie, że analogicznie biskup mógłby konstytuować panegiryk biskupi. Dziś zamierzam podjąć ówczesne spostrzeżenie.

Moje wystapienie jest jedynie rekonesansem - jak najdalszy od tzw. topiki afektowanej czy fałszywej skromności, zdaję sobie sprawę, że trzy teksty (Oda XXXVII w Tomasza Tretera Teatrze cnót światobliwego Stanistawa Hozjusza oraz dwa dramaty eucharystyczne toruńskich jezuitów z lat osiemdziesiątych XVII w.), to skrajnie wąska podstawa jakichkolwiek genologicznych wypowiedzi. Jeśli jednak występuję (jako konferencyjny referent), to $\mathrm{w}$ przekonaniu, że wybrane przeze mnie teksty są przynajmniej w poważnej mierze reprezentatywne dla panegiryku biskupiego Prus Królewskich. Analogicznie jak panegiryk królewski wymaga podziału na pododmiany gatunkowe, uwarunkowane jakże zróżnicowanymi sytuacjami panegirycznymi

Uniwersytet Mikołaja Kopernika w Toruniu.

J. Okoń, Wstęp, [w:] Dramaty eucharystyczne Jezuitów. XVII wiek, opr. idem, Warszawa 1992, s. 15.

3 Panegiryk królewski jest determinowany tym, że „władca jako najważniejszy element świata przedstawionego piórem panegirysty określał zarazem wysokość wyniesienia jak też wykorzystywane mechanizmy dźwigni panegirycznej" (K. Obremski, Panegiryczna sztuka postaciowania: August II Mocny (J. K. Rubinkowski, „Promienie cnót królewskich...”), Toruń 2003, s. 155). 
(tego podziału - przyznaję - przed laty nie dokonałem), tak też panegiryk biskupi powinien zostać podzielony na pododmiany. Zajmę się jedną, tą mianowicie, która jest determinowana geografią Kościoła w Polsce, tj. szczególną sytuacją: biskupi chełmińscy wobec rządzonego przez protestantów Torunia. Toteż klasyfikacja genologiczna stanie się wielostopniowa: rodzaj wymowa popisowa i poezja sylwiczna, gatunek - panegiryk $^{4}$, odmiana gatunkowa - panegiryk biskupi, pododmiana gatunkowa - panegiryk biskupi Prus Królewskich (za takim rozszerzeniem toruńskich wydarzeń i tekstów nimi kształtowanych przemawia ich podobieństwo do tego, co ówcześnie działo się w Elblagu i jak było przedstawiane, np. w odach oraz miedziorytach Tomasza Tretera).

\section{Sytuacja panegiryczna}

Dlaczego Prusy Królewskie kształtują swoistość analizowanej przeze mnie pododmiany gatunkowej panegiryku? Odpowiedź znajduje się w tym, co Marcin Kromer w Polonii pisał o biskupach diecezji warmińskiej i chełmińskiej:

Biskupi wraz ze swymi kapitułami również posiadają swoje zamki, a także namiestników okręgów i burgrabiów oraz swoich sędziów, wójtów i urzędników do spraw kościelnych, tak biskup warmiński, jak i chełmiński. Przysługuje im bowiem jurysdykcja kościelna jak i świecka, a wobec swoich poddanych najwyższa władza.

[...] Również miasto Elbląg wraz ze swym obszarem należy do diecezji warmińskiej, jakkolwiek od pewnego już czasu skażone heretycką zarazą próbuje się wymknąć spod kościelnej jurysdykcji Biskupa, korzystając z pobłażliwości królów i przychylnego stanowiska niektórych urzędników ${ }^{5}$.

Chociaż Kromer niczego podobnego o Toruniu nie napisał, to jednak można mówić o podobnej sytuacji w tych dwu miastach Prus Królewskich: miastach rządzonych przez protestantów w Rzeczypospolitej co prawda tolerancyjnej, ale instytucjonalnie katolickiej (Rex catholico esto!). Wyjątkowa w skali państwa niezależność trzech wielkich miast Prus Królewskich, przewyższających nią nawet miasta rezydencjalne królów polskich - Kraków i Warszawę - splatała się ze zwycięstwem reformacji: w 1558 r. miasta te otrzymały zgodę królewską na głoszenie ewangelii według wyznania augsburskiego ${ }^{6}$. Tak więc $\mathrm{z}$ jednej strony

4 Ibidem, s. 155.

5 M. Kromer, Polska, tłum. St. Kazikowski, wstęp, opr. R. Marchwiński, Literatura Warmii i Mazur w Dawnych Wiekach, pod red. A. Wakara, Olsztyn 1984, s. 199.

6 S. Salmonowicz, Protestanci i katolicy $w$ jednym mieście: casus Torunia $w$ XVIIXVIII w. Przyczynek do dziejów tolerancji religijnej $w$ Polsce, [w:] idem, W staropolskim Toruniu XVI-XVIII w. Studia i szkice, Toruń 2005, s. 6-7. 
biskupi chełmińscy i warmińscy uważali Toruń i Elbląg za miasta poddane ich władzy, z drugiej zaś tamtejsi protestanci nie uważali bynajmniej siebie za ich poddanych. Toteż począwszy od połowy XVI w. relacje między biskupami a tymi miastami, być może najłatwiej określić mianem wojny pozycyjnej ${ }^{7}-\mathrm{w}$ stanie chwiejnej równowagi raz jedna, raz druga strona odnosiła większe lub mniejsze zwycięstwa, jednak o czyimkolwiek finalnym tryumfie niepodobna mówić. Konflikty między protestanckimi miastami Rzeczypospolitej z jej katolicyzmem jako religią panującą a biskupami diecezji chełmińskiej splatały się z konfliktami ustrojowymi, były bowiem zarazem konfliktami między miastami cieszącymi się wyjątkową niezależnością od władz państwowych a tąże władzą z biskupim tronem sprzymierzoną.

\section{Panegiryk biskupi Prus Królewskich versus fakty historyczne}

Panegiryk jest gatunkiem ,rozciąniętym” pomiędzy retoryką a poezją ten swoisty status genologiczny nakazuje przywołać rozróżnienie zwerbalizowane przez kogoś tak istotnego dla staropolskiej teorii genologicznej, jak Maciej Kazimierz Sarbiewski:

[...] prawdopodobieństwo retoryczne i poetyckie z gruntu i istoty swojej są różne. Po pierwsze dlatego, że prawdopodobieństwo retoryczne formalnie osiaga się przez dowodzenie, poetyckie zaś wcale nie, a tylko przez kunsztowny układ opowiadania. [...] Po drugie, prawdopodobieństwo retoryczne ma najczęściej cel istotny i ostateczny wzbudzenie wiary, iż w rzeczywistości tak się stało, podczas gdy poetyckie niekiedy zmierza jedynie do wywołania przekonania, że tak mogło lub powinno się było stać, jeśli w ogóle coś takiego zaszłoby w rzeczywistości ${ }^{9}$.

Zważywszy sytuację panegiryczna, musimy przyjąć, że wszystkie trzy teksty, uświetniające zwycięstwa Hozjusza i Opalińskiego nad toruńskimi heretykami, z pewnością są konstytuowane prawdopodobieństwem retorycznym: mają ,za cel istotny i ostateczny wzbudzenie wiary, iż w rzeczywistości tak się stało", tj. ci dwaj biskupi chełmińscy zwycięsko zmierzyli się z protestantami rządzącymi największym miastem ich diecezji ${ }^{10}$.

7 S. Salmonowicz relacje katolicyzmu i protestantyzmu w dziejach nowożytnego Torunia określił jako „niespokojne współistnienie” (ibidem, s. 8, 20).

8 Szerzej: K. Obremski, op. cit., s. 153-159.

9 M. K. Sarbiewski, O poezji doskonałej, tłum. M. Plezia, opr. St. Skimina, Wrocław 1954, s. 214.

10 Poza zakresem moich spostrzeżeń pozostaje konflikt Hozjusza z Elblągiem, pełniej obecny w dziele T. Tretera. 
Ta wiara w obydwa zwycięstwa zostanie jeśli nie przekreślona, to przynajmniej podważona wówczas, kiedy zgodnie ze słowami Sarbiewskiego zapytamy o dowodzenie jako drogę wiodącą do prawdopodobieństwa retorycznego. W dziele Tretera tekst ody XXXVII De actis Torunensibus

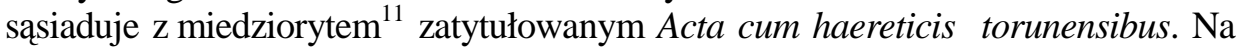
niewielkim podwyższeniu siedzi Hozjusz, przed nim stoją toruńscy heretycy. Hozjusz mówi - oni słuchają. Hozjusz w oratorskim geście podnosi lewą rękę - oni stoją znieruchomiali. Stojący najbliżej widzą, że heretyk trzyma w ręku nakrycie głowy - również pozostali stoją z odkrytymi głowami. Tych pięć opozycji (wyżej niżej, siedzenie - stanie, mówienie - słuchanie, ruch - bezruch, głowa okryta głowy odkryte) jednoznacznie określa kto jest kim: katolicki biskup naucza i tym samym nawraca heretyków. Ta zwycięska dla Hozjusza sytuacja koresponduje z tekstem ody: trucizna nauczania heretyckiego mistrza została zwalczona, a zatrute nią owce pasterza są przywrócone do zdrowia mocą jego nauczania.

Jeśli prawdopodobieństwo retoryczne ma na celu - twierdził Sarbiewski - wzbudzenie wiary, „,iż w rzeczywistości tak się stało”, to czy taki cel został osiagnięty? Trudno o jedną odpowiedź:

- w mikroświecie ody De actis torunensibus i miedziorytu Acta cum haereticis torunensibus zwycięstwo Hozjusza jawi się jako fakt jednoznaczny,

- w makroświecie, tj. w dziejach Torunia, o jakimkolwiek zwycięstwie mówić niepodobna.

Biskup Julian Wojtkowski, a więc ktoś, kogo o jakąkolwiek wrogość wobec Hozjusza posądzić niepodobna, o wydarzeniach uwiecznionych $O d q$ $X X X V I I$ i miedziorytem Tretera pisze tak:

Dnia 16 marca 1551 roku [Hozjusz] przybył do Torunia i stwierdził opuszczenie wezwań świętych w litanii z winy rektora szkoły Urbana Somera. Zachęcił wiernych do komunii św., upomniał magistrat, starał się pouczyć rektora szkoły ${ }^{12}$.

${ }^{11}$ T. Treter. Teatr cnót świqtobliwego Stanistawa Hozjusza, opr. T. T. Ulewiczowie, tłum. E. Buszewiczowa, Kraków 1998 (Ode XXXVII i miedzioryty; przedruk fotograficzny ód oraz rycin bez paginacji).

12 J. Wojtkowski, Czynności religijne Stanistawa Hozjusza w diecezjach: chetmińskiej $i$ warmińskiej 1549-1569, [w:] Kardynat Stanistaw Hozjusz (1504-1579). Osoba, myśl, dzieło, czasy, znaczenie, red. S. Achremczyk, J. Guzowski, J. Jezierski, Olsztyn 2005, s. 78. 
Mniejsza o to, że owa szkoła to słynne w Europie gimnazjum akademickie. Ważniejsze co innego - mianowicie uważnie wczytajmy się w owe słowa ks. bpa Juliana Wojtkowskiego i zapytajmy o skuteczność Hozjuszowej perswazji w mieście rządzonym przez heretyków:

1. „[Hozjusz] przybył do Torunia i stwierdził opuszczenie wezwań świętych w litanii z winy rektora szkoły Urbana Somera" - próżno szukać wiadomości o tym, że w wyniku Hozjuszowych nauk owe wezwania świętych powróciły do litanii,

2. Zachęcił wiernych do komunii św.” - nawet jeśli ta zachęta była skuteczna, to nie wolno abstrahować od kwestii tak istotniej, jako to, kim byli owi wierni i jakie było ich znaczenie? - otóż nawet jeśli liczebnie z czasem katolicy będą stanowić w XVII w. ok. 50\% ludności miasta, to będzie to ,generalnie ludność uboga, nie posiadająca praw miejskich i wpływu na życie miasta"13,

3. „upomniał magistrat” - ale z jakim skutkiem? zerowym? wszak nic nie wiadomo o jakiejkolwiek reakcji upomnianego magistratu,

4. „starał się pouczyć rektora szkoły” - już forma niedokonana „starał się” dostatecznie werbalizuje daremność biskupich pouczeń.

Gwoli sprawiedliwości: Hozjuszowa perswazja przynajmniej jeden raz okazała się skuteczna w walce z heretykami, jednak zwycięstwo, jakim w dziele Tretera jawi się wygnanie Jana Sebastiana Fausera z Wiednia, było jedynie „odsunięciem od [skłaniającego się ku luteranizmowi] Maksymiliana jego kaznodziei nadwornego" ". Co więcej, a raczej co gorsza, dla Hozjusza pasterza i tym samym retora - biskup bynajmniej nie przekonał kaznodziei nadwornego do porzucenia błędnych nauk, lecz jedynie (jak czytamy w Odzie L) wywarł wpływ na cesarza i ten podjął decyzję o wygnaniu. Tak więc skuteczność Hozjuszowej perswazji okazuje się ograniczona do Wiednia i uszu katolickiego cesarza - natomiast uszy heretyków własnej diecezji pozostają na nią głuche. Inna sprawa, że nadworny kaznodzieja syna cesarskiego Maksymiliana w odzie został ukazany jedynie jako ludowy kaznodzieja - także taka „degradacja” nakazuje z ostrożnością traktować historyczną wiarygodność dzieła Tretera. Ostrożność ta jest uwarunkowana również pochwałą jako gatunkiem retorycznym: powinna być ona przedmiotem oceny jedynie estetycznej, nie zaś etycznej. Wszak w wymowie pokazowej materią istotną nie jest zawartość mowy, lecz jej artyzm ${ }^{15}$.

13 S. Salmonowicz, op. cit., s. 11.

14 A. Szorc, Rola dziejowa kardynała Stanistawa Hozjusza, [w:] Kardynat Stanistaw Hozjusz (1504-1579), s. 108.

15 „Przedmiot mowy, który rozpatrywany jest poważnie w genus iudicale i genus 
O ponad wiek późniejszemu biskupowi chełmińskiemu, Kazimierzowi Janowi Opalińskiemu, toruńscy jezuici zadedykowali dwa dramaty eucharystyczne (w 1684 r.: Chrystiernus II król duński i szwedzki oraz w 1687 r.: Wieczerza wielka). Interpretacja alegoryczna powiązana z pojmowaniem czasu jako „wielkiej teraźniejszości” ${ }^{16}$ połączyła religijną więzią osoby oddalone od siebie czasem i przestrzenią: panujący w początkach XVI w. Chrystiernus, król kananejski Adonibezek (ok. 1200 przed Chr.) i Opaliński w latach osiemdziesiątych XVII w. Pierwszy mimo złożenia obietnicy amnestii dla swoich szwedzkich przeciwników miał na sumieniu morderstwo senatorów i przywódców zbrojnego oporu; drugi siedemdziesięciu królom kazał odciąć kciuki u rąk i duże palce u nóg (Sdz 1,5-7). Tym, co łączy z Opalińskim tak zdawałoby się rozłączne postacie, jest Ciało Boże jako tertium comparationis porównania: król duński złamał przyrzeczenie „Najświętszym Sakramentem umocnione”, królewski „bankiet Adonibezeka” swą marność ujawnia w przeciwstawieniu Wieczerzy Pańskiej, obydwaj królowie są zaś jedynie negatywnym tłem dla Opalińskiego, który tryumfalnie prowadzi procesje Bożego Ciała po ulicach Torunia.

Zarysowana dramatami eucharystycznymi postać biskupa jest heroiczna i zwycięska. Patrząc historycznie: tylko heroiczna, on bowiem był tym, który z niewątpliwą odwagą prowadził procesje Bożego Ciała trasą wiodącą na Rynek Staromiejski. Jakakolwiek myśl o trwałym zwycięstwie Opalińskiego nad toruńskimi heretykami już w rok po przedstawieniu Wieczerzy wielkiej okazała się iluzją:

Zjechał i w 1688 r., odprawił z wielką wystawnością procesje, ale nazajutrz gmin miejski opadł na przód służbę biskupa, idącą za kupnem żywności na targ miejski, i wśród urągowisk i bicia zawlókł do więzienia na ratuszu, „szlachtę i woźnego królewskiego, którzy więźniów tych z uprzejmości odwiedzili, w równie dziki sposób krwawią, kilku prałatów katedralnych i księży, do asysty biskupiej przybyłych, obalają na ziemię, strzałami z rusznic i inną bronią wiele im po całym ciele ran zadaja, w twarz

deliberativum, nie ma dla słuchacza [wypowiedzi należącej do rodzaju pokazowego] istotnego znaczenia; jest on traktowany po prostu jako możliwość pokazowego ćwiczenia w sztuce oratorskiej, podczas gdy w genus iudicale i genus deliberativum znaczenie mowy wypływa wyłącznie z jej przedmiotu. [...] Genus ten [tj. demonstrativum] pielęgnuje l'art. pour l'art. («sztukę dla sztuki»): mówca pokazuje swą sztukę oratorską wobec zaproszonej publiczności, która nie wyraża praktycznego sądu odnoszącego się do zawartości mowy, lecz ocenia (podziwia) sam artyzm”. (H. Lausberg, Retoryka literacka. Podstawy wiedzy o literaturze, wstęp, tłum., oprac. A. Gorzkowski, Bydgoszcz 2002, s. 134-135).

16 Szerzej: K. Obremski, „Wielka teraźniejszośc” $i$ alegoreza jako konteksty sarmackiego mesjanizmu. „Barok” 2004, R.XI, nr 1(21), s. 105-117. 
im plują. Wreszcie biskupa samego (w jego domu) biorą w ścisłe oblężenie, nie dopuszczając nikomu ani wyjścia, ani wejścia. A jakie z ust tego gminu wychodziły bluźnierstwa na Najśw. Sakrament, na duchowieństwo, na władzę biskupią przy ustawicznym waleniu we drzwi Rezydencji biskupiej i krzykach, trudno powtórzyć”. Trwało to przez całą noc aż do 10-ej rano, gdy biskup, zdobywszy się na odwagę, wyszedł w otoczeniu kilku służących, przedarł się przez tłum i schronił do kościoła św. Jana ${ }^{17}$.

Z konfrontacji obydwu dramatów eucharystycznych toruńskich jezuitów z faktem tak bezdyskusyjnym, jak tumult 1688 r., wyłania się konkluzja: obydwa teatralne tryumfy biskupa Opalińskiego są jedynie jezuicką propagandą sukcesu, ponieważ unieważniają rzeczywistość. Mniejsza jednak o to, jak owa propaganda jest zrobiona $^{18}$, ważniejsze niech będzie pytanie o poetykę panegiryku biskupiego Prus Królewskich.

\section{Poetyka panegiryku biskupiego Prus Królewskich}

Zważywszy panegiryczną, „niezgodną zgodność” ody z dzieła Tretera i toruńskich dramatów eucharystycznych, należy oddzielnie czytać owe teksty,

\section{A. Oda XXXVII i miedzioryt}

Jakiejkolwiek ody z dzieła Tretera, określonego przez Tadeusza Chrzanowskiego mianem biografii emblematycznej ${ }^{19}$, nie należy jedynie czytać. Należy bowiem czytać i jako kontekst konieczny lektury przyjmować miedzioryty. A może nawet odwrotnie? Znamienne są słowa Janusza Pelca z 2002 r.:

Emblematyczna biografia Hozjusza w wykonaniu Tretera jako całość zawierająca i ryciny, i teksty nie doczekała się dotąd pełniejszej i wnikliwej oceny. Więcej uwagi poświęcono samym rycinom. I nie bez kozery. Treter - jak sądzę - był zdolniejszym rytownikiem, artystą plastykiem niż poetą. W poezji raczej nie wykraczał ponad przeciętność, choć wielu obszernym jego odom pisanym w horacjańskich rytmach

S. Załęski, Jezuici w Polsce, t. IV, cz. II, Kraków 1904, s. 728 (ortografia i interpunkcja uwspółcześnione).

18 Zob. K. Obremski, Jezuicki dramat eucharystyczny jako propaganda sukcesu (Toruń lat osiemdziesiatych wieku XVII), [w:] Komunikacja i komunikowanie w dawnej Polsce, red. K. Stępnik, M. Rajewski, Lublin 2008, s. 181-187.

19 T. Chrzanowski, Działalność artystyczna Tomasza Tretera, Warszawa 1984, s. 84116. 
trudno odmówić pewnego wdzięku i są one cennym źródłem informacji o działalności Hozjusza z bliska oglądanej przez Tretera ${ }^{20}$.

Faktycznie, oda $\mathrm{Na}$ wydarzenia toruńskie jawi się tekstem konwencjonalnym: pochwały dwóch biskupów chełmińskich (Hozjusza i jego następcy Piotra Kostki) splatają się z opowiadaniem o trudach, jakich sobie nie szczędził pasterz zbłąkanych owiec. Nawet jeśli uznać, że pomyślne zwieńczenie duszpasterskiej wizyty Hozjusza w Toruniu jest faktem jedynie literackim, historycznie zaś po prostu fałszywym (dosłownie: pobożnym życzeniem Tretera), to badaczowi literatury dawnej na takiej konstatacji poprzestać nie wolno. Ponieważ to historycznie fałszywe pokrzepienie katolickich serc w pełni wpisuje się w starożytną tradycję panegiryku. Wszak Arystoteles, pisząc o pochwale jako gatunku wymowy popisowej, jest autorem trzech zdań, które neutralizują pytanie o faktograficzną wiarygodność ody Tretera. Autor Retoryki napisał:

Pochwała jest rodzajem mowy, która uwypukla wielkość dzielności etycznej. Przedstawione czyny muszą więc być tego potwierdzeniem. [...] Czyny są zaś przejawem postawy człowieka i stąd możemy również wygłosić pochwałę tego, który jeszcze nie dokonał chwalebnych czynów, jeśli można wierzyć, że ich dokona ${ }^{21}$.

Tak też rzecz ma się w dziele Tretera: zanim Hozjusz przyjechał do Torunia, aby odwieść jego mieszkańców od heretyckich nauk i praktyk, wcześniej wykazał się postawą, która „tam i wówczas” pozwalała przynajmniej niektórym katolikom wierzyć, że w przyszłości doprowadzi do zwycięstwa wiary rzymskiej nad luterskimi nowinkami. Jednak już w dłuższej perspektywie wiara ta staje się iluzją. Zarazem patrząc historycznie, należy pamiętać o tym, że: 1. co prawda w 1549 r. Hozjusz został biskupem diecezji chełmińskiej, jednak był nim krotko (niespełna dwa lata), zaś $\mathrm{z}$ powodu legacji dyplomatycznej rezydował w niej zaledwie kilka miesięcy, 2. w dziejach diecezji warmińskiej jego pontyfikat był najdłuższy i chociaż spośród dwudziestu ośmiu lat zasiadania na tronie biskupim Hozjusz ponad połowę spędził poza diecezją, jednak ,głównie on zahamował niebezpieczny katolicyzmowi rozwój reformacji na Warmii” ${ }^{22}$. To powstrzymanie mogło rodzić nadzieję, że jeszcze nastąpi przejście od obrony do kontrofensywy będącej ostatecznym

20 J. Pelc, Stowo i obraz. Na pograniczu literatury i sztuk plastycznych, Kraków 2002, s. 175.

21 Arystoteles, Retoryka. Poetyka, tłum., wstęp, komentarz H. Podbielski, Biblioteka Klasyków Filozofii, Warszawa 1988, s. 109.

22 A. Szorc, op. cit., s. 100. 
zwycięstwem wiary nad herezją, jednak nie żywił tej nadziei nawet sam Hozjusz: w 1558 r. udał się do Rzymu również dlatego, że był zmęczony walką z elblążanami, wpadł $\mathrm{w}$ depresję i chciał oddalić się od diecezji ${ }^{23}$. Gdyby pozostał biskupem chełmińskim, najprawdopodobniej jego walka $\mathrm{z}$ torunianami zakończyłaby się podobnym wynikiem.

\section{B. Dramaty eucharystyczne.}

Niezmiennie pozostaję przekonany, że ,panegiryczna przesada” jako główna czy nawet jedyna determinanta panegiryku jest zubożeniem, a nawet wręcz okaleczeniem tego bodaj najliczniej reprezentowanego w piśmiennictwie staropolskim gatunku. Zamiast mówić o ,przesadzie” i wikłać się w materię w poważnym zakresie nierozwiązywalną (kiedy pochwała staje się przesadna? dla kogo?), należy zająć się:

- amplifikacją,

- dźwignią panegiryczną z jej znamiennymi mechanizmami wynoszenia,

- statusem panegiryku jako wypowiedzi „rozciagniętej” między retoryką a poezją ${ }^{24}$.

Antyczna teoria retoryczna wyróżniała cztery podstawowe sposoby amplifikacji: incrementum, comparatio, ratiocinatio, congeries. Spośród nich jeden sposób - porównanie - determinuje kompozycję toruńskich dramatów eucharystycznych. Jako heroiczny czciciel Bożego Ciała biskup Opaliński jest elementem dwóch rozbudowanych porównań: 1. zostaje przeciwstawiony świętokradczemu krzywoprzysięzcy Chrystiernusowi oraz okrutnemu i wbrew wystawnej uczcie marnemu w wymiarze eschatologicznym Adonibezekowi; 2. jako pasterz Kościoła, stojący na czele procesji Bożego Ciała, jest kimś „pośrodku” między katolikami Prus Królewskich a Jezusem Chrystusem żyjącym w Najświętszym Sakramencie i dzięki temu ,pośredniemu” statusowi ten, który „pokazuje nosząc Chleb anjelski po rynkach i ulicach toruńskich"25, w mikroświecie dramatu eucharystycznego staje się kimś poniekąd nadludzkim. Co prawda dawna teoria retoryczna „dźwigni panegirycznej” z jej mechanizmami nie znała, jednakże przynajmniej w moim osobistym przekonaniu można o niej mówić i dlatego zapytajmy o to, jakie to mechanizmy tejże

\footnotetext{
23 Ibidem, s. 108.

24 K. Obremski, Panegiryczna sztuka postaciowania..., s. 149.

25 Chrystiernus II król duński i szwedzki, [w:] Dramaty eucharystyczne Jezuitów, s. 170. Gwoli ścisłości: jedynie po Rynku Staromiejskim.
} 
dźwigni zostały $w$ toruńskich dramatach wykorzystane ${ }^{26}$. Jest ich przynajmniej sześć:

a. piekielno-niebieski zasięg uczuć, tzn. zważywszy, że:

- biskup Opaliński zostaje przedstawiony jako zaprzeczenie Chrystierna i Adonibezeka oraz jako dziedzic czci okazywanej Bożemu Ciału przez cesarza Karola V oraz głowy koronowane całej Europy,

- kult Bożego Ciała jawi się jako główna miara religii chrześcijańskiej,

- można odnieść wrażenie, że ulice Torunia stają się centrum świata w jego religijnym wymiarze (ludzkość zostaje podzielona na prawowiernych katolików i bluźnierczych protestantów i ten podział najmocniej wyraża się w procesyjnym ,tu i teraz"),

b. wywyższanie i przewyższanie: ,,[Akt trzeci] Wieczerzę większą nad wielkie

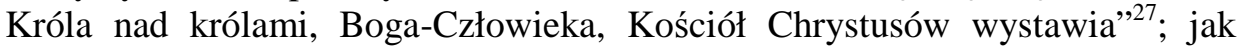
katolicy stoją wyżej niż protestanci, tak czcicieli Bożego Ciała przewyższa biskup Opaliński, żarliwiej czczący je niż katolickie wzory owej czci,

c. Bóg siłą wywyższającą: eucharystyczna pobożność Opalińskiego jest unaoczniona przez znamienne postacie alegoryczne, tj. przez Religię, Nemezis Boską, Mądrość Boską, Zelusa, Wiarę Świętą,

d. biało-czarny obraz świata i zaświatów: w świecie przedstawionym toruńskimi dramatami eucharystycznymi podziały są proste - czciciele Bożego Ciała versus bluźniercy i tym samym niebo versus piekło,

e. arbitralna selekcja faktów: procesja ulicami Torunia była zarazem faktem rewolucyjnym (poprzednicy Opalińskiego nie odważali się na nią poprzestawali na procesjach jedynie po przykościelnym cmentarzu), jak też czymś zgodnym z wcześniejszą o cztery dziesięciolecia umową (w 1643 r. pod naciskiem króla szczegółowo wytyczono „zakres dozwolonej procesji Bożego Ciała mającej odtąd prawo wstępu na Rynek Staromiejski ściśle wytyczoną trasą i na określonych warunkach") ${ }^{28}$; i o jednym (jak było przed Opalińskim), i o drugim (tryumf wpisuje się w zakres porozumienia sprzed czterech dziesięcioleci) dramaty toruńskich jezuitów milczą,

f. „faktotwórcza” siła interpretacji: utożsamienie części (tj. toruńskich katolików) z całością (tj. z mieszkańcami Prus Królewskich) pozwala twierdzić

26 Szerzej o dźwigni panegirycznej i jej mechanizmach, [w:] K. Obremski, Panegiryczna sztuka postaciowania..., passim.

27 Wieczerza wielka, [w:] Dramaty eucharystyczne Jezuitów, s. 176.

28 S. Salmonowicz, Uroczystości i imprezy staropolskiego Torunia (XVI-XVIII w.), [w:] idem, W staropolskim Toruniu, s. 33. 
o Nawie (tj. herbowej Łodzi Opalińskich), że „Pruska Ziemia z tryumfem ją u siebie wita",29.

Owe sześć mechanizmów to tylko o jeden więcej od połowy tych, które wynosiły głowy koronowane ${ }^{30}$, jednak należy powstrzymać się od wyciagania wniosków stąd płynących, ponieważ panegiryk królewski był odmianą gatunkową o wiele bardziej liczebną i stał się przedmiotem analizy gruntowniejszej i dokonanej na nieporównywalnie szerszej podstawie tekstowej niż to moje konferencyjne wystapienie.

Siłę, z jaką panegiryk jest ,rozciagnięty” między retoryką i poezją, kształtuje bliska tożsamości relacja między wymową popisową a poezją, od której ostatecznie rozróżnia ją brak formy metrycznej ${ }^{31}$. Jednak problem panegiryku biskupiego w tak wąskim zakresie, jak ten tu przyjęty (tj. zaledwie trzy teksty), nie wynika bynajmniej stąd, że tylko oda Tretera jest wypowiedzią wierszowaną. Abstrahując od pytania, czy jej wartość literacka pozwala mówić aż o poezji, stajemy właściwie bezradni wobec problemów najzwięźlej określanym słowami ,ikonosfera” i ,audiosfera"32. jak kształtowała się ówczesna (!) relacja między perswazją słowem poety a perswazją obrazem miedziorytnika? czy sumariusze teatralne toruńskich dramatów eucharystycznych pozwalają nam zdobyć chociażby dostateczne wyobrażenie o przedstawieniu teatralnym nim uwiecznionym?

Jeśli panegiryk biskupi Prus Królewskich faktycznie byłby pododmianą gatunkową, wówczas warunkiem koniecznym takiej klasyfikacji genologicznej byłoby wskazanie analogicznych pododmian, uwarunkowanych specyfiką zasiadania na tronach biskupich $w$ innych diecezjach. Ostatecznie zapewne nieprzypadkowo autorem przedmowy do Biblii J. Wujka był metropolita gnieźnieński i prymas koronny abp Stanisław Karnkowski. Z kolei czy genius loci charakteryzuje panegiryki pisane biskupom krakowskim? - czarnoleski Psałterz Dawidów i dedykacja Piotrowi Myszkowskiemu pozostaje znakiem ostrzegawczym przed jakimkolwiek automatyzmem. Czy Lwów determinował silniejszą obecność problematyki wojen Krzyża i Półksiężyca? Nawet jeśli można mówić o zróżnicowaniu terytorialnym, to czy jest ono na tyle poważne, że pozwala na wyodrębnienie pododmian panegiryku biskupiego? Jedynie cząstkowym argumentem, wskazującym na odpowiedź twierdzącą, może być to, że ta przesłanka pochwały Hozjusza, jaką było wypędzenie innowierców z kościołów bezprawnie przez nich zajętych, nie była dana każdemu biskupowi.

\footnotetext{
29 Chrystiernus II król duński i szwedzki, s. 170.

30 K. Obremski, Panegiryczna sztuka postaciowania..., passim.

31 H. Lausberg, op. cit., s. 136.

32 H. Dziechcińska, Ogladanie i stuchanie w kulturze dawnej Polski, Warszawa 1987, passim.
} 
Jeśli jednak już panegiryk biskupi zostanie wyodrębniony jako pododmiana gatunkowa, wówczas stajemy przed wieloma problemami szczegółowymi i jednym zarazem bardzo ogólnym, a podstawowym, tj. strukturą „siatki genologicznej”. Zacznijmy od tych pierwszych, tylko dwóch, uosobionych dwoma postaciami: Jana Kochanowskiego i Jakuba Wujka.

Czarnoleski Psałterz Dawidów poprzedza dedykacja:

\section{JEGO MIEOŚCI \\ Memu Miłościwemu Panu \\ JEGO MIEOŚCI KSIĘDZU PIOTROWI MYSZKOWSKIEMU, $Z$ ŁASKI BOŻEJ BISKUPOWI KRAKOWSKIEMU ETC ${ }^{33}$}

W samych wierszach dedykacji Piotr Myszkowski jednak jakby już nie jest biskupem - jawi się jako mecenas, którego z czarnoleskim poetą łączą więzi bardzo bliskie. Problem nie polega bynajmniej tylko na tym, że biskupi status Myszkowskiego jest jakby przesłonięty wdzięcznością, jaka zdominowała słowa dedykacji. Jakże bowiem mówić tu o panegiryku biskupim, skoro Myszkowski jest biskupem tylko formalnie, by nie powiedzieć: tytularnie? ${ }^{34}$ A jednak o sytuacji panegirycznej należy tu mówić - niezależnie od przekonania, że Kochanowski do poziomu, potocznie przez współczesną polszczyznę określanego pogardliwie słowem „,wazelina”, nie zniżył się, ponieważ: ,nie był pochlebcą i panegirystą. Rola biskupa, nowego Mecenasa, polegała na wspieraniu przedsięwzięcia, i to właśnie honorowała pochwała”, Jeśli zapytamy, na czym polegało owo „wspieranie przedsięwzięcia”, a więc jakież to dobrodziejstwo uwiązało serce Kochanowskiego, wówczas aura antypanegirycznej bezinteresowności jeśli nie znika, to przynajmniej zostaje opatrzona znakiem zapytania.

Tym, co pozwala zakwestionować najczystszy, tzn. antypanegiryczny status dedykacji, są dwa fakty biograficzne: to dzięki poparciu podkanclerzego Piotra Myszkowskiego w 1563 r. Kochanowski otrzymał godność sekretarza królewskiego, zaś siódmego lutego następnego roku został proboszczem katedry w Poznaniu - po dobrowolnym zrzeczeniu się z tej funkcji przez tegoż Piotra Myszkowskiego. Probostwo kapitulne poznańskie dzierżył Kochanowski przez całe dziesięć lat: $1564-1574^{36}$. I nic w tym, zdawałoby się, podejrzanego,

J. Kochanowski, Psałterz Dawidów, wstęp, opr. K. Meller, Kraków 1997, s. [67].

„Kochanowski oczywiście Psałterz swój dedykował mecenasowi-przyjacielowi, który aktualnie był biskupem krakowskim, a nie po prostu biskupowi". (J. Pelc, Jan Kochanowski. Szczyt renesansu w literaturze polskiej, Warszawa 1980, s. 411). K. Meller, Wstęp, [w:] J. Kochanowski, op. cit., s. 11.

36 O prepozyturze: E. Majkowski, Jan Kochanowski, proboszcz kapituły katedralnej poznańskiej, [w:] Kochanowski. Z dziejów badań i recepcji twórczości, wstęp, 
wszak posiadał cztery mniejsze święcenia kapłańskie. A jednak zwerbalizowana słowami dedykacji aura antypanegirycznej bezinteresowności wywołuje podejrzenie, że całkiem konkretny interes materialny pozostaje przesłonięty cnotami mecenasa: otóż dochody związane z poznańską prepozyturą pozwoliły Kochanowskiemu podwoić majątek. W kontekście tej jednej dedykacji tron biskupi pozostaje czymś jedynie instrumentalnym (daje możliwości wsparcia materialnego). To, co dla literatury polskiej jest mecenatem, dzięki któremu czarnoleski poeta mógł napisać dzieło określone słowami „I wdarłem się na skałę pięknej Kaliopy", dla historii Kościoła pozostanie czymś, co nieładnie współczesna polszczyzna określa słowami „,dojna krowa”37, i co nakazywało, oczywiście w skali mikro, podjąć dzieło kontrreformacji pojmowanej jako reforma wewnętrzna instytucji kościelnej.

Inny problem wiąże się z przedmową, jaką Jakub Wujek poprzedził przekład Psatterza Dawidowego z 1594 r. Przekład zadedykowany arcybiskupowi gnieźnieńskiemu i prymasowi Stanisławowi Karnkowskiemu.

Tę tedy pracą moję i ten wszytek Psatterz abo raczej tę małą Biblię (póki się więtsza nie zgotuje) W[aszej] M[ilości] swemu Miłościwemu Panu, dobrodziejowi i fundatorowi naszemu, ze wszytką chęcią ofiaruję, oddawam i przypisuję. A to nawięcej dla trzech $\operatorname{przyczyn}^{38}$.

Wśród tych trzech przyczyn (umiłowanie Księgi Psalmów przez Karnkowskiego, wdzięczność jezuity dla dobrodzieja zakonu i schronienie się tłumacza przed atakami przeciwników jego przekładu) ta ostatnia zasługuje na szczególną uwagę - w kontekście tzw. Biblii Wujka z 1599 r. Otóż ta jedna przyczyna brzmi niczym dopowiedzenie słów ze strony tytułowej: „Pod rozsądek Kościoła Ś. powszechnego rzymskiego wszystko niech podlęże”, mianowicie ta:

Trzecia przyczyna jest, aby ten mój przekład Psałterza, od W[aszej] M[ilości] nawyższego w Polszcze między duchowieństwem wodza i pasterza wdzięcznie przyjęty i aprobowany, stał się tym ważniejszy i innym wszytkim tak duchownym, jako

wybór, oprac. M. Korolko, Warszawa 1980, s. 103-108.

37 „Będąc proboszczem kapituły najstarszego w Polsce kościoła i biorąc z tego tytułu obfite dochody, Kochanowski zupełnie nie dbał ani o swój kościół katedralny, ani o prepozyturę samą. Akta kapitulne nie wspominają o jakiejkolwiek ofierze na rzecz katedry lub na utrzymanie beneficjum. Nie ma również wzmianki, żeby poeta kiedykolwiek Poznań odwiedził". (Ibidem, s. 108).

38 Cyt. za: J. Kochanowski, Psałterz Dawidów, tłum. J. Wujek, Kraków 1594, s. 15. $\mathrm{W}$ cytatach $\mathrm{z}$ tego wydania zmodernizowano ortografię oraz interpunkcję. 
i świeckim stanom tym zaleceńszy i przejemniejszy; a pod mocną imienia Twego tarczą i obroną od przeciwników był tym bezpieczniejszy ${ }^{39}$.

Korzystając z terminologii współczesnej teorii literatury, można by powiedzieć, że owe słowa Jakuba Wujka to alegacja: autorytet biskupa gnieźnieńskiego i prymasa w jednej osobie potwierdza prawowierność przekładu. Instytucjonalnie z tym autorytetem nie mógłby równać się autorytet żadnego innego biskupa Rzeczypospolitej - czy tym samym można mówić o dwóch pododmianach panegiryku biskupiego, determinowanych nie tyle geografią Kościoła, ile hierarchią biskupów? Tzn. można wyróżnić panegiryk biskupi gnieźnieński i nie-gnieźnieński? A więc $\mathrm{z}$ pododmianami determinowanymi geografią (Prusy Królewskie i reformacja, Kraków i mecenat, Lwów i zagrożenie tureckie itp.) współistniałyby pododmiany wyróżnione na podstawie innego kryterium, tj. hierarchii wewnątrz episkopatu?

Powtórzę: jeśli panegiryk biskupi zostanie wyodrębniony jako pododmiana gatunkowa, wówczas stajemy przed wieloma problemami szczegółowymi i jednym zarazem bardzo ogólnym, a podstawowym, tj. struktura ,,siatki genologicznej”. Na czym ten ostatni polega? Mówiąc najkrócej: na tym, że odmiany i pododmiany gatunkowe panegiryku współtworzą klasyfikację, która wydaje się wyzwaniem skazanym na ułomność. Tak z powodu liczebności polskich panegiryków (w okresie wyznaczonym latami 1551-1800 Wilhelm Brzuchnalski naliczył 11771 ,produktów panegirycznych”) ${ }^{40}$, jak też wielości kryteriów, według których poszczególne odmiany i pododmiany mogą być wyróżniane.

Jakież odmiany panegiryku można wyodrębnić $\mathrm{z}$ tegoż niemal dwunastotysięcznego bezmiaru ,,produktów panegirycznych”? Jeśli przyjąć, że owe odmiany są konstytuowane statusem społecznym wywyższanej osoby, wówczas należy mówić przynajmniej o sześciu odmianach: królewskiej ${ }^{41}$, magnackiej ${ }^{42}$, szlacheckiej, biskupiej, mieszczańskiej i akademickiej. Każda z tych odmian dzieli się na pododmiany, jedynie przykładowo:

- panegiryk królewski - jego podział na pododmiany wyznacza chronologia: elekcja - koronacja - okres panowania (np. epinicia) - śmierć,

39 Ibidem, s. 16.

40 W. Bruchnalski, Panegiryk, [w:] Dzieje literatury pięknej w Polsce, cz. 2, Kraków 1918, s. 208.

41 Zob. K. Obremski, Panegiryczna sztuka postaciowania..., passim.

42 Zob. idem, Sapiehowie $i$ panegiryk magnacki (,Mowa księdza Benedykta Rusieckiego na pogrzebie Kazimierza Władysława Sapiehy), [w:] Dwory magnackie w XBVIII wieku. Rola i znaczenie kulturowe, red. T. Kostkiewiczowa, A. Roćko, Warszawa 2005, s.41-55. 
- panegiryk magnacki i panegiryk szlachecki - tu kryterium podziału może być stanowione biegiem ludzkiego żywota: od genetliakonu przez epitalamium po funeralia,

- $\quad$ panegiryk biskupi - kryteria geograficzne czy hierarchiczne oczywiście nie wykluczają innych,

- panegiryk mieszczański - znamienne, że w kasie Gdańska rezerwowano pewne sumy na panegiryki zamawiane przez miasto; jeśli przyjąć podział sformułowany przez Edmunda Kotarskiego, wówczas można mówić o czterech odmianach panegiryku mieszczańskiego: gratulatoria z okazji powołania na urząd - poezja urodzinowa i imieninowa - poezja epitalamijna - funeralia $^{43}$,

- panegiryk akademicki - tę odmianę gatunkową można podzielić (za Ewą Jolantą Głębicka) na dwie grupy: panegiryki powstałe z okazji ważnych wydarzeń państwowych czy uroczystości kościelnych oraz te powstałe z okazji czysto uniwersyteckich (bakalaureat, doktorat, profesura) ${ }^{44}$.

Samoistnym zagadnieniem pozostanie pytanie o panegiryk chłopski: czy twórczość jedynie oralna wyklucza to, że również stan kmiecy stanie się przedmiotem wywyższenia? Nawet jeśli przyjąć, że piśmienność pozostaje warunkiem koniecznym panegiryzmu, to czyż sielanka Żeńcy nie jawi się przynajmniej swoistą pochwałą wieśniaków? Analogicznie słowa Piotra Skargi jako obrońcy tych, o których później będzie mówić się, że ,żywią i bronią”.

Zarazem niepodobna rozstrzygnąć, czy to podział na wiersz i prozę nie powinien stać się podstawowym kryterium wyróżnienia odmian gatunkowych panegiryku. Może zaś, zważywszy wcielanie się panegiryku w rozmaite formy gatunkowe, takim podstawowym kryterium powinna stać się dawna genologia z jej ówczesnymi podziałami na rodzaje i gatunki?

W niczym nie umniejszając wielorakich problemów, stanowionych klasyfikacją genologiczną, należy dopowiedzieć, że to nie ona ani dawna konwencja literacka czy nawet język łaciński dawnych panegiryków wydają się problemem zarazem najważniejszym i najtrudniejszym. Nim bowiem jest konwencja bardziej społeczna niż literacka. Cóż bowiem przywoływać upomnienia o wakanse $\mathrm{z}$ ich zgodnymi zapewnieniami izby poselskiej i tronu

43 E. Kotarski, Gdańska poezja okolicznościowa XVIII wieku. Gdańsk 1997; zob. idem, Gdańska poezja okolicznościowa XVII wieku, Gdańsk 1993.

44 E. J. Głębicka, Akademia Krakowska a twórczość panegiryczna w XVII w., [w:] Literatura i instytucje w dawnej Polsce, red. H. Dziechcińska, Warszawa 1994, s. 50-51; zob. U. Wich-Szymczak, „Liber passus Klemensa Stanisława Herki: panegiryk z okazji awansu akademickiego. Problemy komunikacji literackiej poprzez poezje kunsztowna, druk w niniejszym tomie na stronach 275-290. 
o tym, że im król biedniejszy, tym bardziej kochany przez poddanych i tym samym mocniej zasiadający na tronie ${ }^{45}$, skoro nawet współcześnie już zanikający zwyczaj całowania kobiet w rękę jednym jawi się jako element konstytutywny polskiej tożsamości narodowej, innym zaś jedynie jako cmoknonsens. Cóż również mówić o nekrologach z ich pogrążeniem żałobników w rozpaczy...

45 Por. K. Obremski, Wakanse - „do, ut des”, [w:] Między barokiem a oświeceniem. Nowe spojrzenie na czasy saskie, red. K. Stasiewicz, S. Achremczyk. Olsztyn 1996, s. 257-260. 